\title{
Navetta 4.0 - navetan olosuhteiden jatkuva mittaaminen
}

\author{
Olli Koskela ${ }^{1}$, Katri Virtanen ${ }^{2}$, Joni Kukkamäki ${ }^{3}$, Ilmo Aronen ${ }^{4}$, Iivari Kunttu ${ }^{5}$
}
1)HAMK Smart -tutkimusyksikkö, Hämeen ammattikorkeakoulu, Hämeenlinna, olli.koskela@hamk.fi
2) Hämeen ammatti-instituutti,Tammela, katri.virtanen@hamk.fi
3) HAMK Smart -tutkimusyksikkö, Hämeen ammattikorkeakoulu, Hämeenlinna, joni.kukkamaki@hamk.fi
4) Lantmännen Feed Oy, Turku, ilmo.aronen@lantmannenfeed.fi
5) HAMK Smart -tutkimusyksikkö, Hämeen ammattikorkeakoulu, Hämeenlinna, iivari.kunttu@hamk.fi

\section{TIIVISTELMÄ}

Ennen maitoa myytiin hinkkeihin tilalla, mutta tänään se tehdään tonkallisella dataa, vaikka maitopurkin omistajanvaihto tapahtuukin kaupassa. Datan keruun ja esineiden Internetin mahdollistama ruokaketjun vaiheiden tunteminen on tärkeää monestakin näkökulmasta, kuten ruokaturvallisuus, raaka-aineiden tehokkaan käytön parantaminen, ostajan eettisten mielipiteiden kunnioittaminen sekä ilmastonmuutoksen ehkäisy. Tässä työssä paneuduttiin navetan olosuhteiden mittaamiseen. Asensimme Hämeen ammattikorkeakoulun Tammelassa sijaitsevaan tutkimusnavettaan lämpötilaa, kosteutta, valoisuutta, hiilidioksidia ja liikettä mittaavat mittalaitteet (ERSCO2, ELSYS). Laitteet toimivat vähän virtaa kuluttavan tiedonlähetyksen LoRaWAN ${ }^{\mathrm{TM}}$-verkossa, joten pitkäaikainen mittaus on mahdollista ilman erillistä virransyöttöä. Mittauslukemat laitteista lähetettiin ja 15 minuutin välein ja ne saapuivat tallennuspaikkaan luotettavasti mittausajanjaksolla. Mittausten perusteella navetan avoimessa tilassa vallitsee melko homogeeniset olosuhteet. Olosuhteiden vaihtelua verrattiin karjan keskimääräisen maidontuotannon vaihteluun ja odotetusti muutokset olivat ajallisesti yhteydessa" toisiinsa, mika" motivoi jatkotutkimuksiin.

\section{Johdanto}

Esineiden internet -ratkaisut ja -lähestymistavat mahdollistavat datan keruun suhteellisen edullisesti erilaisissa toimintaympäristöissä. Tuotantoympäristöjen jatkuva monitorointi ja ruokaketjun vaiheiden tunteminen on tärkeää, jotta voidaan kehittää ruokaturvallisuutta, raaka-aineiden tehokasta käyttöä, ostajan eettisten mielipiteiden huomioimista sekä ilmastonmuutoksen ehkäisyä.

Lehmien ympäristöllä on todettu olevan vaikutusta lypsykäyttäytymiseen ja -tuotokseen. Suotuisten olosuhteiden navetassa on arvioitu olevan määräävä tekijä lehmien vapaaehtoisen lypsyaktiivisuuden kehittymisessä (Rodenburg 2017). Tiheämpi lypsykäyttäytyminen nostaa tuotetun maidon määrää ja toisaalta epäsäännöllisellä lypsyrytmillä on laskeva vaikutus maidontuotantoon, mikä on sitä merkittävämpi, mitä pidempi aika on kulunut poikimisesta (Bruckmaier 2001, Bach ja Busto 2005). Laskuvaiheen jälkeen maidontuotanto normalisoituu noin seitsemässä päivässä olosuhteiden salliessa, mutta menetettyä lypsytuotosta ei saada kompensoitua (Bach ja Busto 2005). Epäsäännöllinen rytmi vaikuttaa myös maidon rasvapitoisuuteen (Friggens ja Rasmussen 2001).

Hämeen ammattikorkeakoulun Tammelassa sijaitsevaan Mustialan tutkimusnavettaan on asennettu helmikuussa 2019 lämpötilaa, kosteutta, valoisuutta, hiilidioksidia ja liikettä mittaavat mittalaitteet (ERSCO2, ELSYS). Tavoitteenamme on ymmärryksen lisääminen navetan rakenteen vaikutuksista siellä vallitseviin olosuhteisiin ja edelleen olosuhteiden vaikutuksista lehmien hyvinvointiin ja lypsykäyttäytymiseen sekämaidontuotantoon.

Mittalaitteiden alkuperäinen valinta perustui sovelluslähtöisyyteen: edullisella kaupallisella teknologialla, jota on helppo monistaa ja jonka avulla voidaan tuottaa mielekäs olosuhdemittaus sekä tilalliselle että tutkimuskäyttöön. Laitteet toimivat vähän virtaa kuluttavan tiedonlähetyksen LoRaWAN ${ }^{\mathrm{TM}}$-verkossa, joten pitkäaikainen mittaus on mahdollista ilman erillistä virransyöttöä.

Tutkimusasetelmaa on loppuvuodesta 2019 täydennetty videokuvalla sekä tarkemmalla suunnittelulla mittauspisteiden valinnan suhteen. Päivittäisen vaihtelun seuraaminen yksilötasolla mahdollistaa reagoimisen poikkeustilanteisiin. Toisaalta myös yksittäin lypsettävien lehmien yksilöllinen palkitseminen lypsykäyttäytymisestä on mahdollista (Jacobs ja Siedford 2012). Tässä artikkelissa raportoimme havaintoja ensimmäisistä kokemuksista navetan olosuhdemittauksissa sekä vertaamme olosuhteita karjankeskimääräiseen maidontuotantoon lämpötila-kosteusindeksin avulla (Dikmen ja Hansen 2009). 


\section{Navetassa tehdyt mittaukset}

Hämeen ammattikorkeakoulun Tammelassa sijaitsevaan Mustialan tutkimusnavettaan asennettiin helmikuussa 2019 lämpötilaa, kosteutta, valoisuutta, hiilidioksidia ja liikettä mittaavat mittalaitteet (ERS-CO2, ELSYS). Merkitään mittalaitteita kirjaimin A-D. Mittalaitteet A, B ja C asennettiin parsien välissä sijaitseviin tukirakenteisiin noin 1,6 m korkeuteen. Sijainnin valinnalla tavoiteltiin mittapistettä lähellä lehmiä, mutta kuitenkin niiden ulottumattomissa. Neljäs mittalaite oli lypsyrobotin yhteydessä. Kuvassa 1 on esitetty laitteiden sijainti pohjakuvan avulla ja Kuvassa 2 on valokuvat laitteista asennettuna.

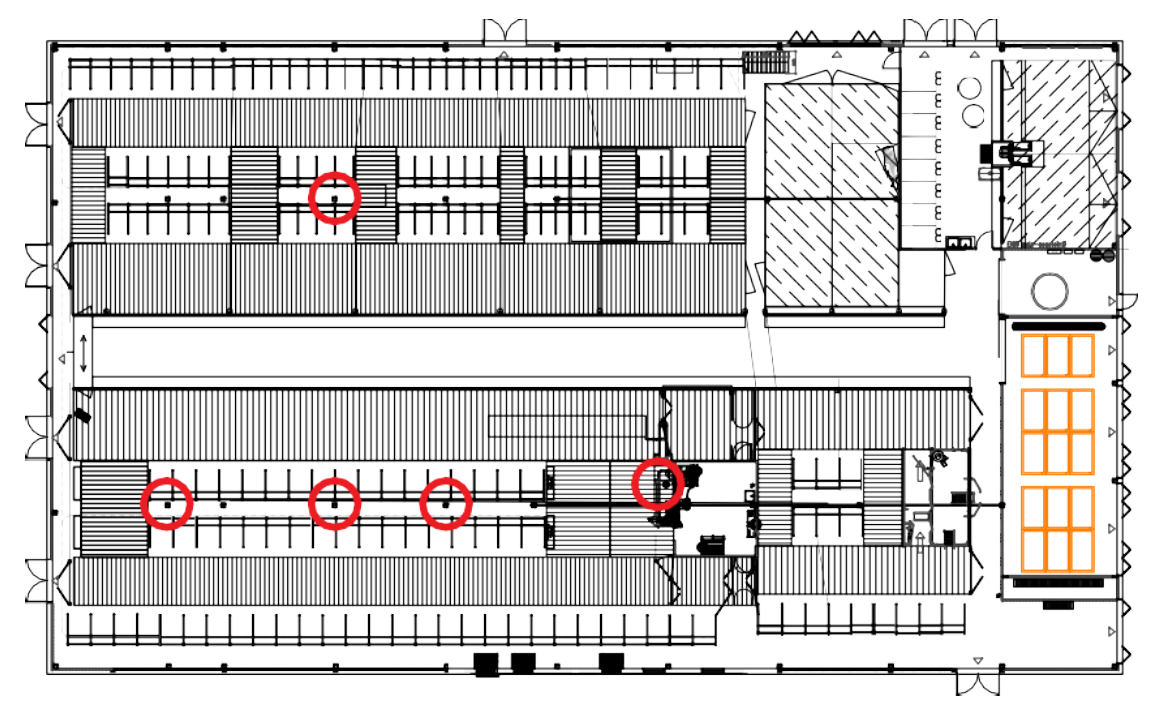

Kuva 1. Navetan pohjakuva ja mittalaitteiden sijainti. ERS-CO2 laitteet A-D sijoiteltiin parsien välissä oleviin tukirakenteisiin lypsävien lehmien alueelle ja on merkitty alaosassa rivissä olevin punaisin ympyröin. Vasemman puoleisin laite on A ja merkintä jatkuu siitä aakkosjärjestyksessä oikealle. Yläosassa on merkitty punaisella ympyrällä mittauskorkeutta testaavien laitteiden asennuskohta E.

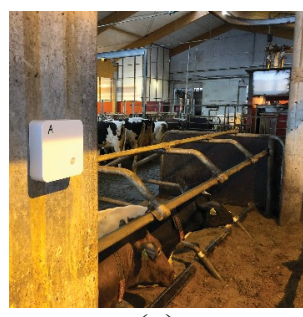

(a)

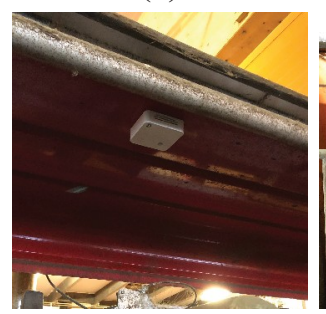

(c)

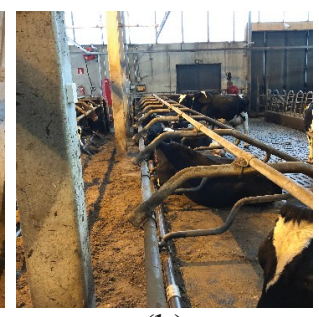

(b)

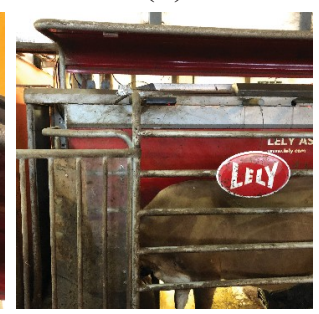

(d)

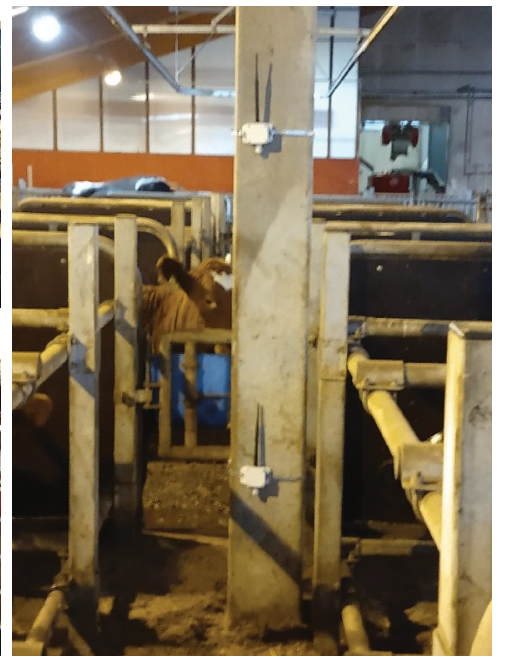

(e)

Kuva 2. (a)-(b) Laitteet A, B ja C ovet parsien välissä olevissa tukipilareissa. (c)-(d) Laite D on asennettu lypsyrobotin katteeseen. (e) Pisteen E laitteiden asennus

Akkutoimiset laitteet toimivat vähän virtaa kuluttavan langattoman tiedonlähetyksen LoRaWAN ${ }^{\mathrm{TM}}$-verkossa, joten pitkäaikainen mittaus on mahdollista ilman erillistä virransyöttöä. Oleellinen tekijä virran- 
kulutuksessa on myös mittausten ja tiedon lähettämisen intervalli. Mittalaitteet asetettiin lähettämään antureiden lukemat 15 minuutin välein. Viestiliikenne mittalaitteista Internetiin kytkettyyn Digitan tallennuspisteeseen tapahtui LoRaWAN ${ }^{\mathrm{TM}}$-verkossa (Digita, Suomi), josta tieto reititettiin edelleen Internetin yli Hämeen ammattikorkeakoulun hallinnoimalle pilvipalvelualustalle (Azure, Microsoft). Pilvipalvelualustalla kaikkien neljän laitteen tietosisältö koottiin yhteen taulukkomuotoiseen tietovarastoon analyysia varten. Analyysissa käytetyt lämpötilan, suhteellisen kosteuden, valoisuuden ja hiilidioksiditason lukemat ovat mittaushetken arvoja. Liikeanturin laskemia liikelukumääriä ei käytetty analyysissa.

Mittalaitteiden A, B ja D lähetyksistä 76-80\% ja C-laitteen lähetyksistä 62\% saapui perille. Pisin jakso, jolloin lähetyksiä ei saapunut kesti 28-33h. Näitä jaksoja oli kaksi: yksi toukokuun ja toinen kesäkuun lopulla. Perille saapuneiden lähetysten väli oli 15 minuuttia 81,7 prosentissa lähetyksiä ja 99\% lähetyksistä saapui alle tunnin välein. Kuvassa 3 on esitetty saapuneiden lähetysten aikavälien histogrammi. Laitteen C lämpötilasensori meni epäkuntoon 17.6. ja laitteen B 10.7. Elokuusta 2019 alkaen käytännössä kaikki laitteet olivat menneet epäkuntoon.

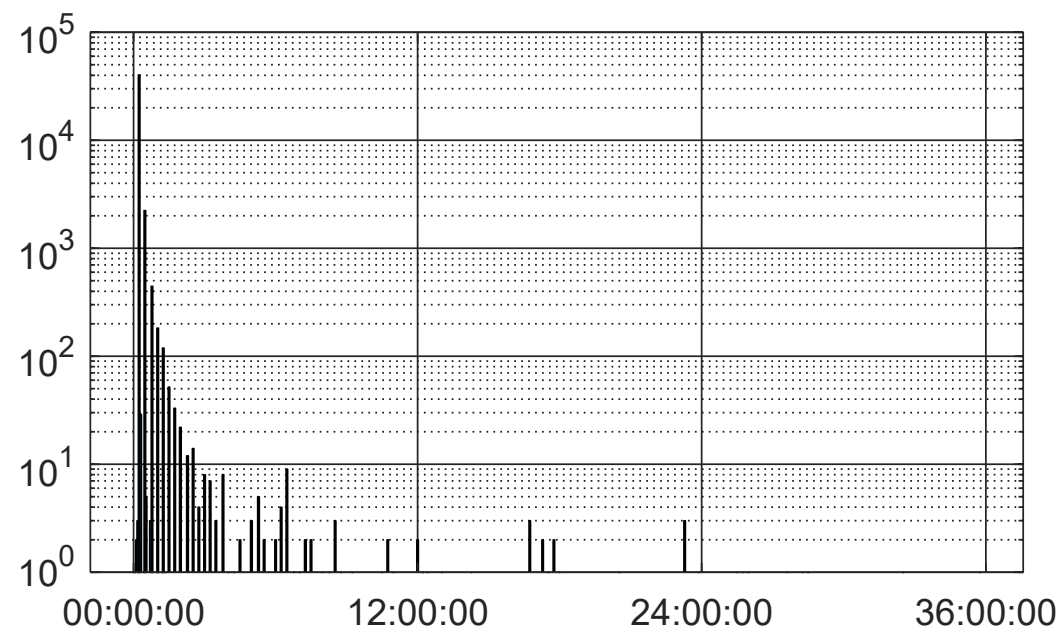

Kuva 3. Histogrammi laitteiden A-D lähettämien lukemien saapumisväleistä. Väleistä 81,7\% on tasan 15 minuuttia ja $99 \%$ on korkeintaan 60 minuuttia. Huomaa logaritminen asteikko pystyakselilla. Vaaka-akselin yksikkö on aika muodossa tunnit:minuutit:sekunnit.

Jatkotutkimusta varten korvasimme mittalaitteet A-D IP67-luokitelluilla mittalaitteilla (ELT-2, ELSYS), jotka mittaavat lämpötilan, suhteellisen kosteuden ja ilmanpaineen. Näillä laitteilla testasimme myös mittauskorkeuden vaikutusta kohdassa E (Kuva 1), jossa yksi laite asennettiin $50 \mathrm{~cm}$ korkeuteen ja toinen $160 \mathrm{~cm}$ korkeuteen samaan tukipilariin (Kuva 2). Ulkoilman säätietona käytimme Ilmatieteenlaitoksen mittauksia Ilmalan sääasemalta (Jokioinen, Suomi), joka on lähinnä Mustialaa sijaitseva sääasema. Etäisyys Mustialasta Ilmalaan on $14.5 \mathrm{~km}$.

\section{Tulokset}

Kuvassa 4 (a) ja (b) on laitteiden A-D sekä säätiedon (W) lämpötila ja suhteellisen kosteuden mittaustulosten päivittäiset keskiarvot. Olosuhteet parsien alueella ovat melko homogeeniset, mutta lypsyrobottiin kiinnitetyn laitteen D yhteydessä ilma oli lämpimämpää ja kuivempaa, mikä on toisaalta oletettavaa koneen läheisyyden ja kiinnityspisteen vuoksi. Kevätkuukausina navetan lämpötilat ovat selkeästi korkeampia kuin ulkolämpötila ja kesäkuukausina ero tasaantuu. Ilman suhteellinen kosteus vaihtelee ulkoilmassa enemmän kuin navetan sisällä, mutta toisaalta kuivina aikoina ero on pienempi kuin kosteina päivinä. 
Kuvassa 4 (c) on laitteiden A-D lämpötilan ja suhteellisen kosteuden mittaustulosten perusteella laskettu lämpötilakosteusindeksi (Dikmen ja Hansen 2009) THI $=T_{\mathrm{db}}+0.36 T_{\mathrm{db}}+41.2$, missä $T_{\mathrm{db}}$ on lämpötilan ja suhteellisen kosteuden avulla arvioitu kastepiste käyttäen Magnusin kaavaa (Lawrence 2005). THI on laskettu vastaavasti myös Ilmatieteenlaitoksen mittauksista ulkoilman lämpötilalle ja suhteelliselle kosteudelle sekä esitetty samassa kuvassa 4 (c). THI:n laskemiseen on käytetty päivittäisiä keskiarvoja. Odotetusti THI:n sekä maidon keskimääräisen päivätuotoksen (M) trendit mukailevat toisiaan, vaikka tässä vaiheessa niiden suhteeseen ei voida ottaa sen enempää kantaa.

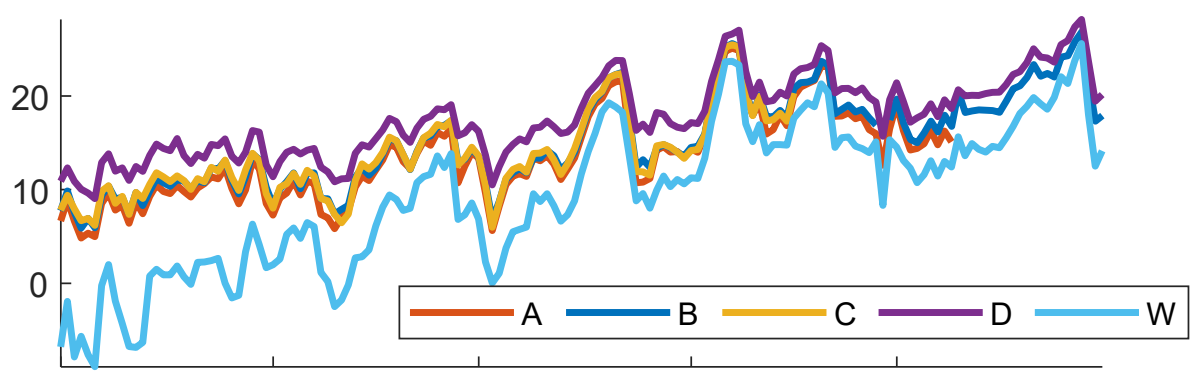

Mar Apr May Jun Jul

(a) lämpötila $\left({ }^{\circ} \mathrm{C}\right)$

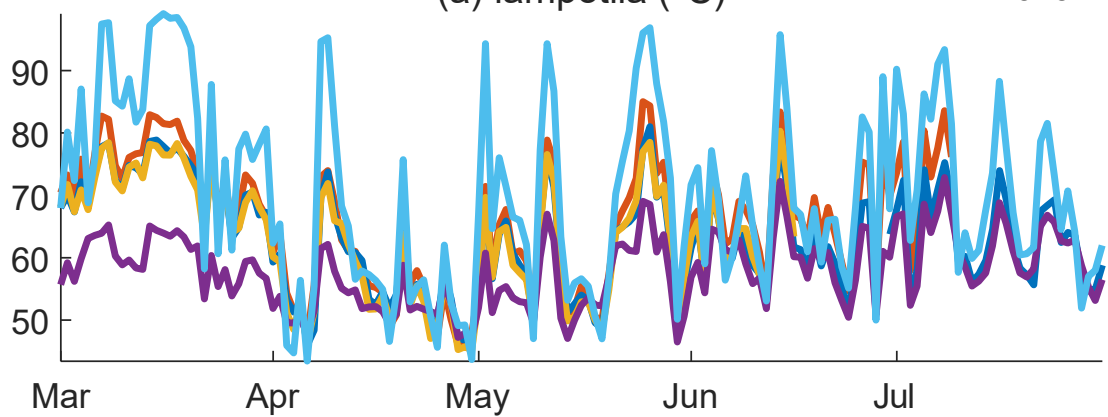

(b) ilman suhteellinen kosteus (\%)

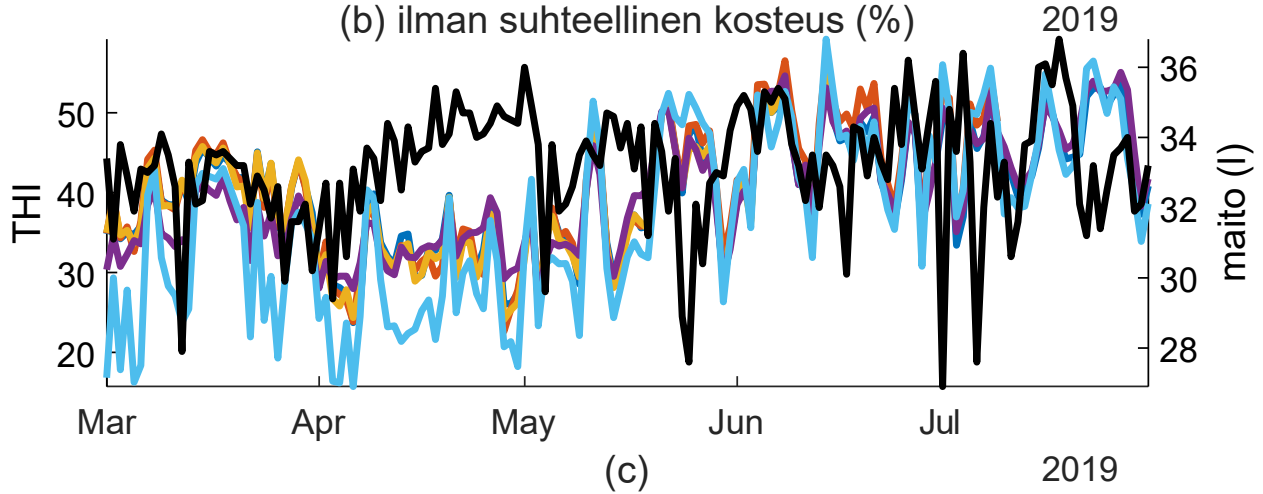

Kuva 4. Vuorokauden keskimääräiset (a) lämpötilat, (b) suhteelliset kosteudet sekä (c) lämpötila-kosteusindeksi versus koko karjan keskimääräinen maidontuotanto per lypsävä lehmä.

Jatkuva mittaaminen mahdollistaa myös päivän sisäisen vaihtelun analysoimisen, mikä onkin yksi sen merkittävimmistä uutuusarvoista navettasuunnittelussa ja eläinten hyvinvoinnin edistämisessä. Kuvassa 5 on esimerkinomaisesti näytetty yhden vuorokauden raakalukemat laitteista A-D. Kuvassa 6 on esitetty seitsemän päivän keskiarvo päivittäisestä vaihtelusta tunnin aikaikkunoissa. Kuvaajista huomataan luonnollinen lämpötilan, suhteellisen kosteuden ja valoisuuden vaihtelu vuorokaudenajan mukaan. Hiilidioksiditasot ovat pysyneet suhteellisen tasaisina vuorokaudenajasta riippumatta, mutta kesäkuukausina, kun tuuletusaukkoja ja ovia pidetään enemmän auki, hiilidioksiditaso on matalampi kuin talvikuukausina. 


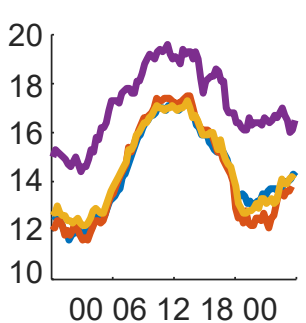

(a)

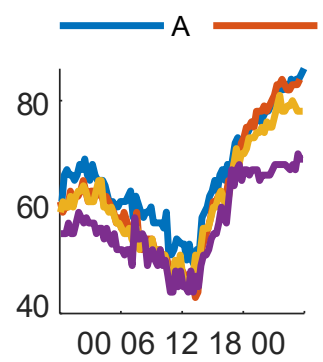

(b)

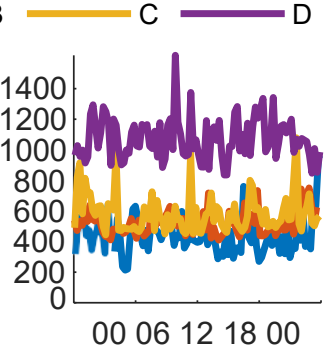

(c)

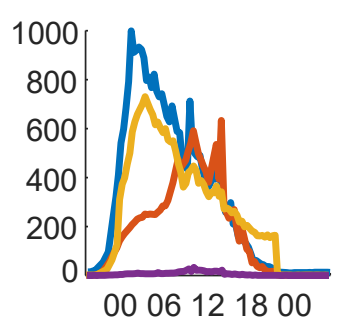

(d)

Kuva 5. Laitteiden A-D mittauslukemat 1.6.2019: (a) lämpötila ( $\left.{ }^{\circ} \mathrm{C}\right)$, (b) ilman suhteellinen kosteus (\%), (c) hiilidioksiditaso (ppm) ja (d) valoisuus (lux)

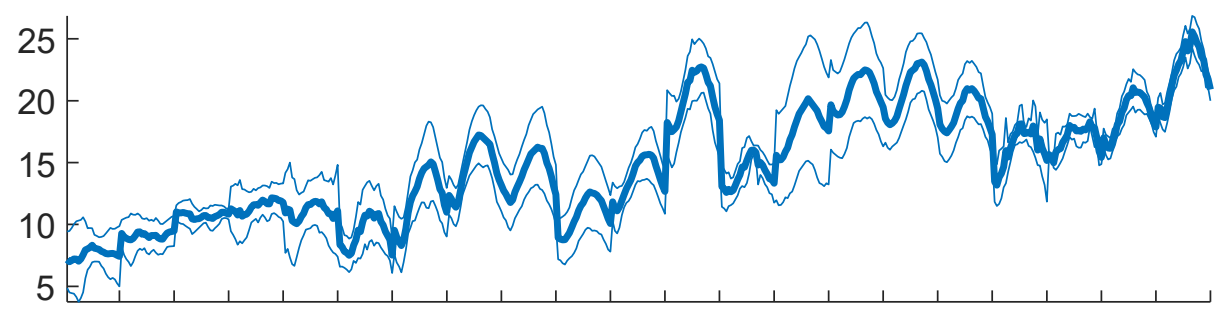

111213141516171819202122232425262728293031

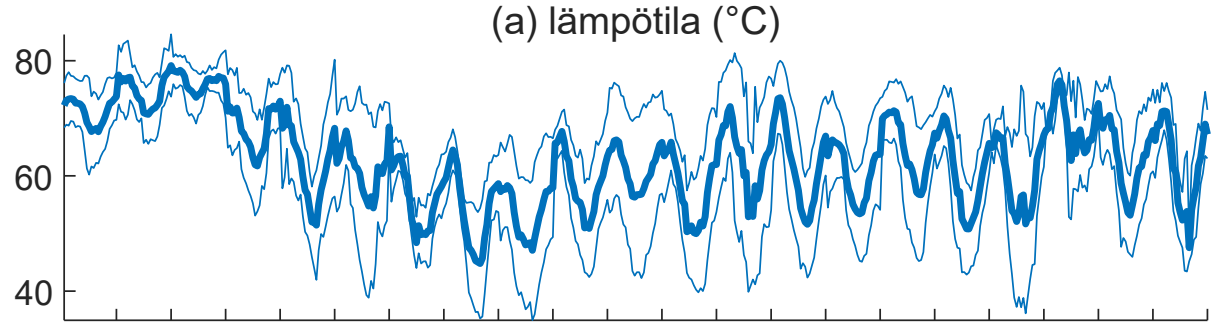

111213141516171819202122232425262728293031

(b) ilman suhteellinen kosteus (\%)

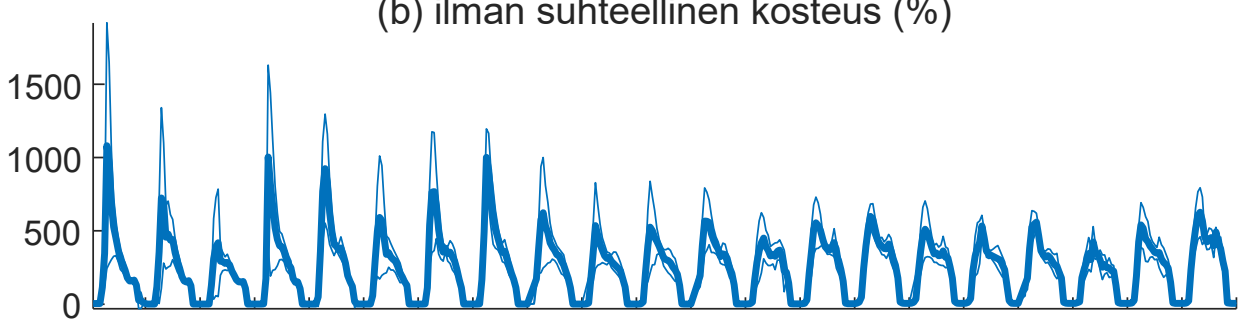

111213141516171819202122232425262728293031

(c) valoisuus (lux)

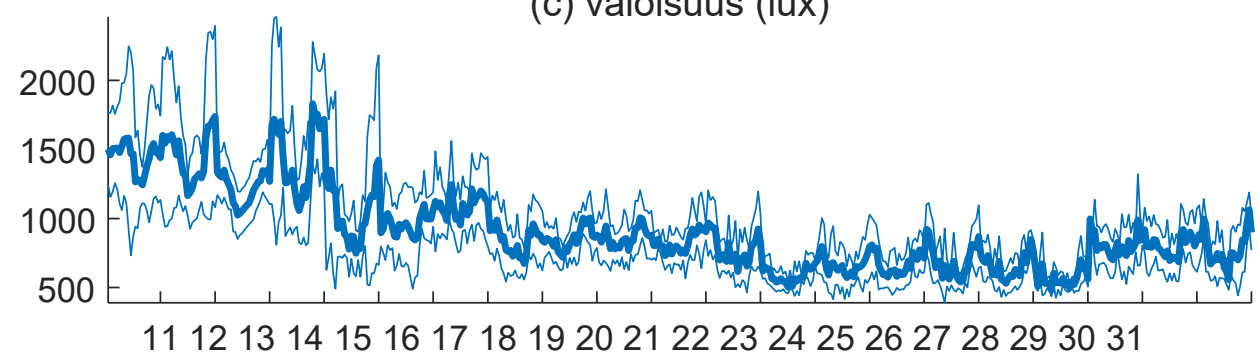

(d) hiilidioksiditaso (ppm)

Kuva 6. Laitteen A keskimäääinen vuorokautinen vaihtelu paksummalla viivalla sekä vuorokautisen vaihtelun keskihajonta ohuemmalla. Vaaka-akselissa viikkonumerot. Toisin sanoen, kahden viikkonumeron välissä on alkavan viikon perjantaista päättyvän viikon torstaihin tunneittaisen keskiarvon keskiarvo sekä keskihajonta. Ilmankosteutta lukuun ottamatta, hajonta pienenee kesäkuukausina verrattuna kevään kuukausiin. 


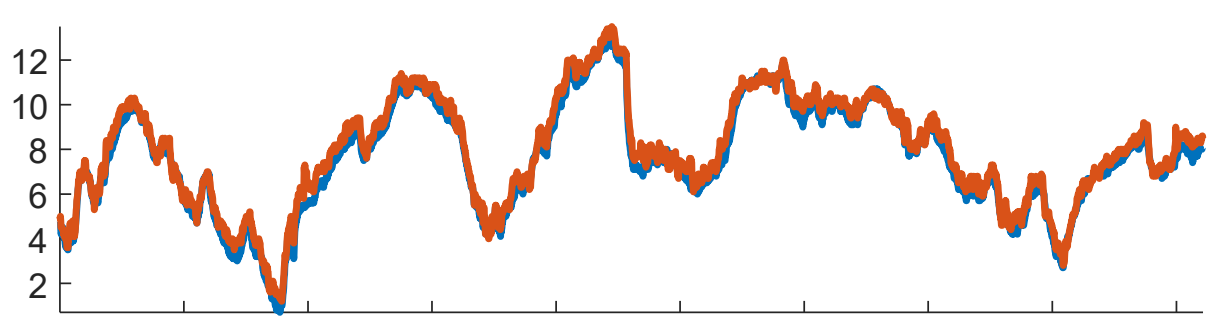

Nov 04 Nov 07 Nov 10 Nov 13 Nov 16 Nov 19 Nov 22 Nov 25 Nov 28

(a) lämpötila $\left({ }^{\circ} \mathrm{C}\right)$

2019

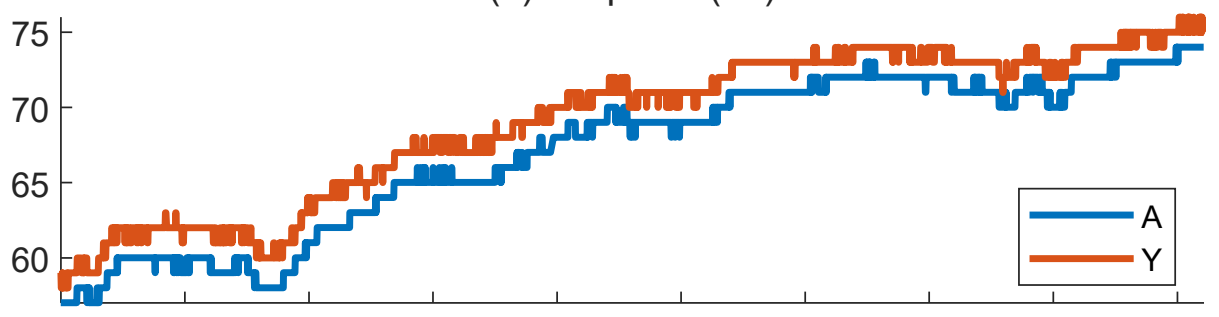

Nov 04 Nov 07 Nov 10 Nov 13 Nov 16 Nov 19 Nov 22 Nov 25 Nov 28

(b) ilman suhteellinen kosteus (\%)

2019

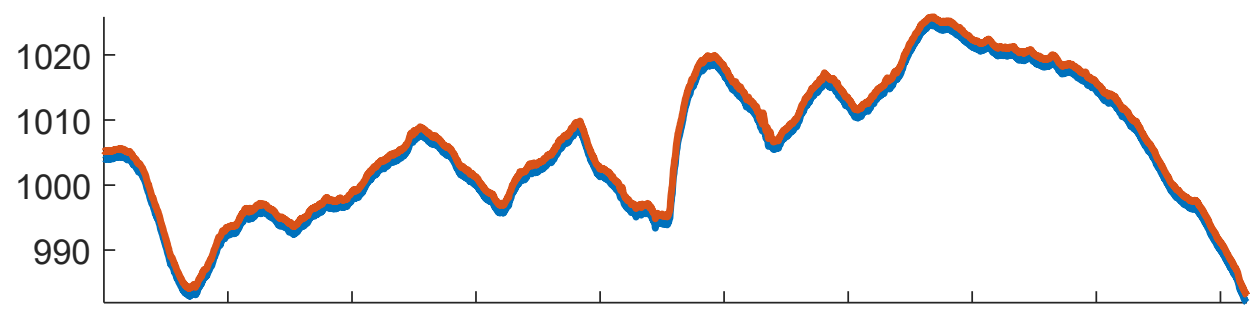

Nov 04 Nov 07 Nov 10 Nov 13 Nov 16 Nov 19 Nov 22 Nov 25 Nov 28

(c) ilmanpaine $(\mathrm{hPa})$

2019

Kuva 7. Lukemat $50 \mathrm{~cm}$ (A) ja $160 \mathrm{~cm}$ (Y) korkeuksiin asetetuilla antureilla E-pisteessä olivat hyvin lähellä toisiaan alustavassa neljän viikon testissä 1.-28.11.2019.

Mittalaitteen asennuskorkeuden vaikutusta tutkittiin pisteessä E kahdella laitteella, joista toinen asennettiin $50 \mathrm{~cm}$ korkeuteen (A) ja toinen $160 \mathrm{~cm}$ korkeuteen (Y). Mittausajanjaksolla 1.-28.11.2019 laitteiden lukemat olivat hyvin lähellä toisiaan, kuten kuvasta 7 nähdään eli asennuskorkeus ei tässä tapauksessa vaikuttanut merkittävästi mittaustuloksiin.

\section{Pohdinta}

Laitteiden A, B ja C lukemat ovat hyvin lähellä toisiaan valoisuutta lukuun ottamatta, joten mittausten perusteella vaikuttaisi, että olosuhteet navetan avoimessa tilassa ovat hyvin homogeeniset. Myöskään asennuskorkeudella ei ollut merkittävää vaikutusta mittauslukemiin testipisteessä. Mittaustarkkuuden vuoksi mittareiden lukemissa näkyy pientä heiluntaa, joka tasoittuu keskiarvoistaessa lukemia vertailukelpoisiin aikaikkunoihin.

Navetan sisäolosuhteet vaikuttavat mielenkiintoiselta mikroilmastolta suhteessa ulkoilmaan. Lämpötila on talvikuukausina selvästi poikkeava ulko- ja sisäolosuhteiden välillä, mutta suhteellinen kosteus sisäilmassa seurailee tarkemmin ulkoilman kosteutta, tosin selkeästi pienemmin vaihteluin.

Lämpötila-kosteusindeksin käyttö tässä yhteydessä on melko yksinkertaistava lähestymistapa, mutta mahdollisti helpon vertailun olosuhteiden ja tuotannon välillä. Tuloksissa näkyvä vahva samanaikaisuus muutoksissa motivoi jatkamaan tutkimusta ja pohtimaan mahdollisia yhteyksia" tarkemmin, erityisesti yksilötasolla. Navetassa olevien lehmien seuraaminen videokuva-analyysin avulla on mainio lähestymistapa täydentämään olosuhdemittauksen ja tuotoksen välistä ajallista jatkumoa, jossa lehmä nauttii uutta ravintoa vallitsevissa olosuhteissa prosessoidessaan myöhemmin lypsettävää maitoa (Porto ym. 2015, Nasirahmadi ym. 2017). 
Kaiken kaikkiaan jatkuvatoiminen mittaus oli näissä puitteissa yksinkertaista toteuttaa ja tiedonsiirto toimi luotettavasti LoRaWAN ${ }^{\mathrm{TM}}$-verkossa. Sisäkäyttöön suunnitellut laitteet eivät kestä navettaympäristössä. Testiajanjaksolla 1.3. -31.7. olosuhteiden ja maidontuotannon muutokset vaikuttavat olevan ajallisesti yhteydessa" toisiinsa, mika" motivoi tutkimuksenjatkamiseen.

\section{Datan saatavuus}

Esitetyt mittaukset ELSYS ERSCO2 laitteilla sekä käytetty Ilmatieteenlaitoksen säädata on saatavilla CCBY4.0 Creative Commons Nimea”-lisenssoituna (Koskela ym. 2020).

\section{Kiitokset}

Tämä tutkimustyö kuuluu Opetus- ja kulttuuriministeriön rahoittaman Biotalous 4.0-tutkimusohjelman piiriin. Vaihto-opiskelijamme Giovanni Da Silva, Leticia Ventura dos Santos ja Thomas Paulo (Instituto Federal de Santa Catarina, Brasilia) toteuttivat ERSCO2 antureiden tiedonsiirron yhdessa" Atte Partasen (HAMK Smart, Hämeen ammattikorkeakoulu) kanssa.

\section{Viitteet}

Bach, A. \& Busto, I. 2005. Effects on milk yield of milking interval regularity and teat cup attachment failures with robotic milking systems. Journal of Dairy Research 72: 101-106. https://doi.org/10.1017/S0022029904000585

Bruckmaier, R., Macuhova, J. \& Meyer, H. 2001. Specific aspects of milk ejection in robotic milking: a review. Livestock Production Science 72: 169-176. https://doi.org/10.1016/S0301-6226(01)00277-9

Dikmen, S. \& Hansen, P.2009. Is the temperature-humidity index the best indicator of heat stress in lactating dairy cows in a subtropical environment? Journal of Dairy Science 92: 109-116. https://doi.org/10.3168/jds.2008-1370

Friggens, N. \& Rasmussen, M. 2001. Milk quality assessment in automatic milking systems: accounting for the effects of variable intervals between milkings on milk composition. Livestock Production Science 73:45-54. https://doi.org/10.1016/S0301-6226(01)00228-7

Jacobs, J. \& Siedford, J. 2017. Robotic milking: Technology, farm design, and effects on work flow. Journal of Dairy Science 95: 2227-2247. https://doi.org/10.3168/jds.2016-11715

Koskela, O., Partanen, A., Kukkamäki, J. \& Kunttu, I. 2020. Barn 4.0 measurements with ELSYS ERS-CO2 device. https://doi.org/10.5281/zenodo.3632702

Lawrence, M. 2005. The relationship between relative humidity and the dewpoint temperature in moist air: A simple conversion and applications. Bulletin of the American Meteorological Society 86: 225-234. https://doi.org/10.1175/BAMS-86-2-225

Nasirahmadi, A., Edwards, S. \& Sturm, B. 2017. Implementation of machine vision for detecting behaviour of cattle and pigs. Livestock Science 202: 25-38. https://doi.org/10.1016/j.livsci.2017.05.014

Porto, S., Arcidiacono, C., Anguzza, U. \& Cascone, G. 2015. The automatic detection of dairy cow feeding and standing behaviours in free-stall barns by a computer vision-based system. Biosystems Engineering 133: 46-55. https://doi.org/10.1016/j.biosystemseng.2015.02.012

Rodenburg, J. 2017. Robotic milking: Technology, farm design, and effects on work flow. Journal of Dairy Science 100: 7729-7738. https://doi.org/10.3168/jds.2016-11715 